\title{
The use of gaan + infinitive in narratives of older bilingual children of Moroccan and Turkish descent ${ }^{*}$
}

\author{
Leonie Cornips \\ Meertens Institute
}

1. Introduction

In this paper, I will focus on the use of the verbal cluster gaan+infinitive 'go' in Dutch jokes told by bilingual children aged between 6 and 13 years of Turkish and Moroccan descent. The children told these jokes at the so-called Salaam Lombok, a multicultural market which is held every year around September in the neighbourhood of Lombok/Transvaal in Utrecht. This neighbourhood is object of research within the TCULT-program (Cornips and Jongenburger 1999). The recordings took place in 1998 and the corpus is collected by all TCULT-researchers.

The Moroccan and Turkish children have told their jokes in Dutch or in their native language Berber and Turkish, respectively. ${ }^{1}$ If we consider the Dutch jokes, it is striking that these bilingual children use the verbal cluster gaan+infinitive, as shown in (1), to a large extent (see Cornips t.a.):

(1) Hij ging springen toen ging 't hij ook proberen toen...

he go-PAST jump-INF then go-PAST it he too try-INP then

hij ging op z'n kop vallen..

[non-indigenous]

he go-PAsT on his head fall-iNP

'He jumped, then he tried it too and then he fell on his head'

In standard Dutch the auxiliary gaan may express inchoative aspect 'is about to' and/or it has a future modal reading 'is going to' and/or it may express that the subject is moving in order to perform his action (zich verplaatsen), as shown in (2a) and (2b), respectively. In addition to gaan, the children also use the auxiliary zullen 'shall' to express future tense, as in $(2 \mathrm{c})$ : 
(2) a. Hij gaat zwemmen

he goes swim-rNF

'He is going to/is about to swim'

b. Hij gaat zijn tas pakken

he goes his bag catch-INF

'He is moving in order to catch his bag'

c. ik $z a l$ het vertellen

I shall it tell

'I will tell it'

[Turkish girl]

Slightly more than half of the children produce gaan+infinitive in their jokes, namely 36 out of 69 . Moroccan and Turkish children do not differ with respect to the use versus the non-use of gaan+infinitive. Further, the high frequency of gaan+infinitive is striking, in particular, the 36 children produce a total number of 86 tokens (see Cornips t.a. for more details). The transcript of their Dutch jokes counts 7,586 words. One recording of two adult women in Lombok/Transvaal speaking monolingual Dutch reveals that they only produce 10 tokens of gaan although their transcript counts 9,239 words. In addition, other recordings of native children of the same age who are telling jokes contain the verbal cluster gaan+infinitive to a far lesser extent.

In this paper, it is argued that the use of gaan is not part of an acquisition procedure to facilitate the acquisition of V2 in Dutch. Instead, it is argued that apart from the future modal reading and inchoative aspect the high frequency of gaan indicates that these older bilingual children produce it to denote an ongoing event This assumption will be supported by the fact that the use of gaan goes hand-inhand with predicates that from an aspectual point of view yield a temporal scale such that every sequence of a subevent does not denote a different point on a timeaxis, that is to say, they do not inherently allow an endpoint. Subsequently, these predicates have aspectual properties such that they express continuation or duration of the event.

The structure of this paper is as follows: Section 2 adresses the question whether gaan acts like a dummy verb due to an acquisition procedure of Dutch as a second language; Section 3 deals with the aspectual restrictions on the verbal cluster gaan+infinitive and Section 4 offers a conclusion and remaining questions.

\section{The use of gaan as an acquisition procedure?}

According to Van Kampen (1997:49), the appearance of dummy verbs in monolingual Dutch child language such as gaan and doen 'do' is related to the acquisition of the V2 structure. In standard Dutch in the matrix clause the finite verb has undergone movement whereas in the embedded clause the finite verb remains in its base- generated position where it follows its complement, as illustrated in (3a) and (3b), respectively:

(3) a. Het kind eet $t_{\mathrm{i}}$ een appel t the child eats an apple

b. Het kind dat een appel eet the child who an apple eats

According to the references cited in Van Kampen (1997:50), the acquisition of moving the finite lexical verb to the second position in the matrix clause is fairly early between 107 and 120 weeks. Before this period, the children already use modals and auxiliaries in this position. The insertion of dummy verbs such as doen 'do' and gaan 'go' takes place simultaneously when the V2 rule starts to apply to lexical finite verbs. The relation between V2 and the use of a dummy verb is established by the facts that in Dutch child language the insertion of gaan (i) is always absent in the embedded clause and (ii) disappears once the V2 rule is clearly established (cf. Van Kampen 1997).

From this, we may posit the hypothesis that the use of gaan such as in (1) can be considered as an acquisition or learning procedure of Dutch as a second language. In examining the data, no gaan+infinitives were found in embedded clauses, as in (4):

(4) a. toen ging de meester kijken of iedereen zijn then go the master look-INF if everyone his haar...sch... afgeknipt hebt hair cut-off has

b. keek 'ie of 'ie het kon halen looked he if he it could make

[non-indigenous]

[Moroccan]

The corpus, however, hardly contains embedded clauses. In this respect, nothing can be said about the possible asymmetrical distribution of gaan in matrix and embedded clauses since more conclusive data is needed. Suppose, however, that the children indeed do not use gaan in embedded clauses. There are strong arguments in favour of the assumption that this strategy, however, has nothing to do with the application of the V2 rule. First, the joke corpus has massive instances of V1 expressing successive actions in the narrative similar to the use of the adverb en toen 'and then', as presented above in (4b) (cf. Bennis t.a.). This 'narrative Vl' indicates that the children master lexical verb movement in the matrix clauses. Second, as we will see in the following section, gaan is used in a very systematic way: that is, it is not simply used in all cases where overt movement of the verb is obligatory. Therefore, it is not very likely that the use of gaan indicates that these bilingual children fail to perform V2. 
Let us now consider the data of the bilingual children in more detail. Strikingly, in contrast to the frequent use of gaan, the corpus shows that the children produce a great range of auxiliaries in Dutch. Some examples are presented in (5) through (8):

Modal auxiliaries kan 'can', mag 'may', moet 'must', wil 'want', and laat 'let'

(5) a. Mag ik een andere vertellen?

[non-indigenous] may I an other tell-inf 'May I tell an other (joke)?'

b. Je moet eerst nog sjampoo doen you must first : shampoo do-INe

[Yunis, Moroccan, 6 yrs]

Aspectual auxiliaries heeft 'have' and is 'is':

(6) a. En krokodil kwam vogeltjes tegen die heeft'ie opgegeten and the crocodile encountered little birds, he has eaten them

b. $\mathrm{Ze}$ is in de sloot gevallen

she is in the ditch fallen-pC

'She has fallen in the ditch'

Copula is 'is' + N/V/A/P predicate

(7) Was de Nederlander bang

'Was the Dutch man afraid'

[non-indigenous]

Locational, aspectual auxiliaries + to infinitive; only $z i t$ 'sit':

(8) Hij zat voetbal te kijken

he sat football to watch-INP

'He is watching football'

[Samir, Moroccan]

\section{The use of gaan and aspectual restrictions}

It is claimed that the high frequency of the verbal cluster gaan+infinitive indicates that in this narrative corpus the bilingual children may use it to express an ongoing event. This reading of gaan+infinitive can also be found in very young monolingual child Dutch. According to Jordans (1990:1433-34) and Van Kampen (1997:46), gaan may be analysed as a grammatical aspectual structure, i.e. it is a progressive structure expressing an ongoing activity, as illustrated in (9a) and (9b), respectively:

(9) a. We gaan allemaal ete $(30 ; 1)$

we go all : eat-1N

'We are all eating'

b. Poes ga slapen (L. 3;6.9)

cat go sleep-InF

'The cat is sleeping'
In Lalleman (1986:75) too, it is argued that young Turkish children use the construction gaan+infinitive as an alternative expression of the present tense, that is to say "as an avoidance of the present tense".

The following fragment of discourse shows that the bilingual children also use gaan+infinitive in the case when the event, i.e. in this case one child is imitating the other has already started. This can not be accounted for if gaan+infinitive expresses only inchoative aspect or a future modal reading: ${ }^{4}$

Child 1: "Jantje was op school, en ze deed steeds broembroem" (non-indigenous) Child 2 [verontwaardigd]: "Hebtie van mij. Hij naapt mij a. Hé, stop stop. Hij naapt, hij naapt mij a. Hij gaat me naäpen." (non-indigenous)

Child 1: 'Jantje was at school and she said increasingly broembroem'

Child 2 [indignant]: 'he has it (the joke) from me, he is imitating me, stop stop he is imitating me, "he goes me imitate-INF"

\subsection{Transitive predicates}

Another source of evidence in support of the assumption that the older bilingual children may produce the cluster gaan+infinitive as an expression of an ongoing event comes from the aspectual restrictions on these predicates. I will show that the use of gaan goes hand-in-hand with predicates having aspectual properties such that they express continuation or duration of the event. To this end, let us consider the transitive constructions including gaan. Figure 1 reveals that 47 out of 86 tokens concern infinitives belonging to the transitive class of verbs of which only 32 contain a direct object:

\begin{tabular}{lcc}
\hline The object consists of: & Total \% \\
& $\mathrm{N}=47$ \\
\hline mass, (bare) plural, collective noun & 20 & $43 \%$ \\
noun that is concrete, singular, countable, referential and definite & 5 & $11 \%$ \\
no object present & 15 & $32 \%$ \\
pronoun & 6 & $13 \%$ \\
other (quote) & 1 & $2 \%$ \\
\hline
\end{tabular}

Figure 1. Gaan-insertions and the type of direct object

Strikingly, the great majority of the direct objects (20 out of $47(43 \%)$ ) consists of nouns that determine the aspectual properties of the VP such that the object is not able to measure out the event. Hence, the direct objects consist of mass nouns, collective nouns, bare singulars and plural nouns. First, the direct object is a mass noun, such as bier 'beer' or a collective noun such as politie 'police' and aardrijks. 
kunde 'geographics' or a non-concrete noun such as nee 'no' in (10a), (10b,c) and (10d), respectively:
(10) a. Marokkaan ging bier, brie halen Moroccan went beer fetch-rNp

b. Toen ging (...) ging die politie bellen then went went he police call-INp

c. Jantje en Jip gingen aardrijkskunde doen en è Jantje and Jip went geographics do-INP

d. En ging tie nee zeggen and went he no say-INF

[non-indigenous]

[Halit: Turk]

[Turk]

[Yunis, Moroccan]

Furthermore, the direct object may consist of a bare singular of a bare plural, as illustrated in (11a) and (11b), respectively. And, the referent of the direct object may express an unspecified quantity, as shown in (11c). Note that both the construction in (10d) and in (1Ic) are unacceptable in Standard Dutch:

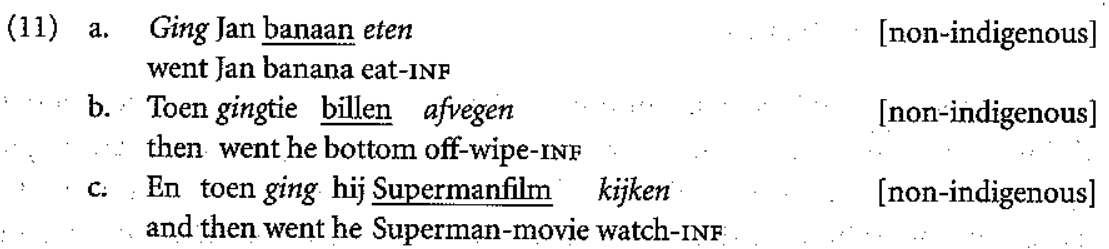

It is assumed that all the objects in (10) and (11) do not have the status of real objects but they must be interpreted as part of the predicate, i.e. as a predicate modifier. Interestingly, De Hoop (1992) argues that if object NPs have to be interpreted as part of a one-place predicate, the phenomenon of object incorporation can be conceived as the final morphological realization of this interpretation. In this respect, the use of gaan signals that object incorporation has taken place. It is remarkable that in this use the bilingual children differ from adult speakers of Dutch in that they apply object incorporation more consistently and adapt the morphologi$\mathrm{cal}$ form of the object to it more frequently. Hence, the constructions in (10b), and (11a,b) are acceptable in adult Dutch if the object is a full DP, such as de politie 'the police', een banaan 'a banana' and zijn billen 'his bottom', respectively. Obviously, the presence of gaan is linked to the aspectual properties of the predicate as a whole such that the object is not able to measure out the event. As a result, the predicates depict the event as atelic i.e. they express continuation or duration of the event

By contrast, 5 out of 47 utterances $(=11 \%)$ involve predicates having a direct object that consists of a noun that is concrete, singular, countable, and definite, as shown in (12). ${ }^{2}$ This means that in (12) the direct object is able to measure out the event. These constructions have the same (incorporation)-interpretation as in (10) and (11) but the objects have the correct definite form. Note that $(12 \mathrm{c})$ is ungrammatical in standard Dutch:
(12) a. toen ging Jantje zijn broek uittrekken then went Jantje his trousers off-take-IN

b. kom ga de televisie uitdoen come go the television out-turn-INF

c. Jantje ging zijn vinger opsteken Jantje went his finger raise-rnp [non-indigenous]

[Harun, Turk]

[Demet, Turk]
However, given this assumption, we would expect that in the majority of cases gaan is absent in transitive predicates with objects that consist of nouns that are concrete, singular and countable as in (12). This expectation is borne out, as illustrated in (13). Surprisingly, the children now produce a concrete, singular and countable noun even when it is unacceptable in adult standard Dutch, as shown in (13a):

(13) a. hij zag een vijfentwintig gulden he saw a twenty-five guilder

b. toen raakte die zijn kontje aan then touched he his bottom part

c. pakt 'ie $\underline{z}$ 'nzakmes catches he his knife

d. toen vond Wietst vond Jantje een knaak then found Wietst found Jantje a two guilders fifty

e. gooide die de schil weg threw he the skin away

[Murad, Moroccan]

[non-indigenous]

[Moroccan]

[non-indigenous]

[non-indigenous]

Finally, in the corpus the use of gaan may apply to infinitives belonging to the class of verbs that are optionally or more or less obligatorily transitive. 15 out of 47 tokens show that the object is absent (see Figure 1 in Section 3.1). By this composition an atelic reading emerges:

(14) a. toen zei de meester... (...) gingtie aaien then said the master (..) went he stroke-INF

b. ik ga wel even uitvegen

I go PART out-sweep-INF

c. ik ga even drinken...

I go for a moment drink-INP

d. ik ga wel zelf zoeken

I go PART by myself look-INF

e. ga maar in je handen doen

go PART in your hands do-INF

[non-indigenous]

[non-indigenous]

[non-indigenous]

[non-indigenous]

[non-indigenous]

To summarise, the children apply object incorporation more consistently and adapt the morphological form of the object to it more frequently than is the case in adult Dutch. Further, the children prefer to leave out the direct object. The aspectual composition of these predicates yield an atelic event, that is to say, they do not inherently allow an endpoint but express the continuation or the duration of the event. 


\subsection{Intransitive predicates}

More evidence is the fact that gaan+infinitive combines easily with infinitives belonging to the unergative class of verbs, as illustrated in (15) (22 out of 39 tokens of intransitive verbs, $56 \%$ ). It is generally accepted that in Dutch unergative verbs forming the perfect tense with the auxiliary hebben denote an event that does not inherently allow an endpoint. All utterances such as in (15) with the exception of (15f) are acceptable in standard adult Dutch. Remarkably, the children use repetition of the infinitive in order to intensify the reading of the continuation of the event, as shown in $(15 \mathrm{~d}, \mathrm{e})$. Moreover, one child combines gaan with the two infinitives blijven staan (remain stand) that is unacceptable in Standard Dutch, illustrated in $(15 \mathrm{~g})$. This utterance clearly expresses the duration of the event:

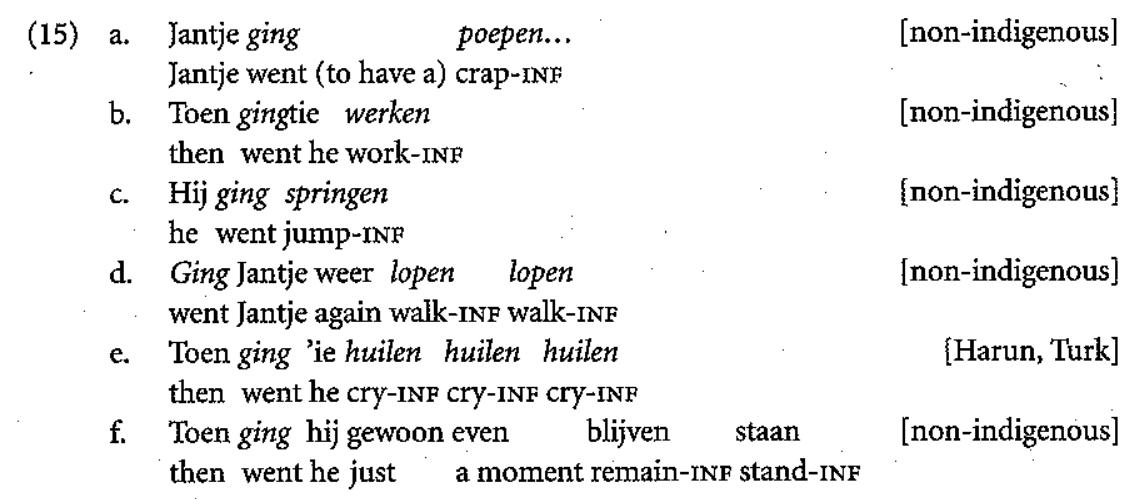

Furthermore, it is predicted that gaan will not occur with infinitives belonging to the unaccusative class of verbs since in general these verbs select $z i j n$ as their perfect auxiliary denoting perfective (resultative) aspect. However, 17 out of 39 tokens constitute counterexamples. The great majority of these tokens, namely 13 out of 17 $(=76 \%)$ concerns the same lexical infinitive vallen 'fall'. Murat, a Turkish boy produces more than the half of these tokens, namely 7 out of 13. Informally, the frequent use of the verb vallen 'fall' is triggered by the point of a particular joke that is very favourite among the children. In addition, by his frequent use of the verbal cluster gaan+vallen-INF Murat does distinguish himself from the other children and, as a result, his data are not representative of the corpus. Besides the fact that this verbal cluster seems to be typical for Murat, the remaining data show that the type-token ratio of the combination of gaan + infinitive-UNACC is 4/17. It is obvious that gaan occurs only with a very restricted subset of possible lexical infinitivesUNACC, as illustrated in (16). ${ }^{3}$ This is in striking contrast to the utterances gaan+ infinitive-UNERG, as discussed above:

(16) a. Toen ging die wegrennen

[Halit, Turk] b. hij ging weer doorlopen he went again walk-on-INF

c. Toen ging de politie komen then went the police come-INF

[non-indigenous]

[Khalid, Moroccan]

With this in mind, we now go on to look at what happens to the other verbs that belong to the unaccusative class. It is predicted that in the majority of cases the children do not insert gaan, i.e. the utterances in (16) are counterexamples. And, indeed, this is the case. Some of the many examples are presented in (17):

(17) a. toen gleed de oma uit uit bananeschil then slipped the grandmother PART banana-skin

b. dan kom ik weer terug then come I again back

c. en hij viel van de boom and he fell off the tree

d. dus meester zei hou maar op thus master said stop (it) PART

e. er komt een geest uit there comes a spirit out

f. de volgende keer viel portemonnee van haar oma [non-indigenous] the next time fell purse of her grandmother

3.3 State verbs

Given the constraint on the aspectual nature of the predicates occurring with gaan, we would also expect that gaan does not combine with verbs denoting states. Hence, it is a common observation in the literature that stative verbs differ from eventive verbs in that the former lack implications of a passage of time. This expectation is borne out. Note that the use of gaan in the constructions in (18) will also lead to an ungrammatical result in Dutch:

(18) a. ik weet niet wat ik wil zeggen... o ik weet 'm I know not what I want say... o I know it

b. ik ken een hele mooie mop in het Marokkaans I know a very beautiful joke in Moroccan.

c. Jantje z'n vriendje heette Homo Jantje his friend was called Homo

d. ze stond niet op het lijstje she stood 'was' not on the list

e. hij had geen geld he had no money
[Turk]

[Moroccan]

[non-indigenous] [non-indigenous]

[Halit, Turk] then went he away-run-INF 


\section{Conclusion}

The very high frequency of gaan+infinitive in Dutch jokes told by bilingual children aged between 6 and 13 years of Turkish and Moroccan descent indicates that in addition to denoting inchoative and future modal readings these children use gaan to describe an ongoing event. More evidence for this assumption comes from the fact that the use of gaan goes hand-in-hand with predicates that from an aspectual point of view yield a temporal scale such that every sequence of a subevent does not denote a different point on a time-axis, that is to say, they do not inherently allow an endpoint. Subsequently, these predicates have aspectual properties such that they express continuation or duration of the event.

In future research, the most important question that has to be addressed is to what extent these bilingual children rely in their use of gaan+infinitive on their L1 grammatical system such as Turkish, Berber or Moroccan Arabic. Future research has to determine whether the use of gaan+infinitive may be considered as evidence for a rather long transitional stage in bilingual children in the sense that bilinguals use gaan in a similar way as monolingual (younger) children do but to a much higher degree (cf. Müller et al 1999).

An intriguing question remains whether from a sociolinguistic point of view the use of gaan may interplay with ethnicity as extralinguistic condition. It might be the case that these older bilingual children exploit their linguistic repertoire such as the high frequency of gaan in attempting to mark social identity in a dynamic multicultural setting brought about by immigration. This raises the following important interrelated theoretical issues (Holmes 1997): (i) is gaan also present by the descendants of immigrants who acquire the new language natively? (ii) is gaan+infinitive significantly related to ethnicity, that is to say, is this features occurring only in Moroccan Dutch and Turkish Dutch?

\section{Notes}

* I like to thank Aafke Hulk. Thanks to Sjef Barbiers for his valuable comments on an earlier version of this paper. Of course, all errors remain mine.

1. The category non-indigenous includes only Moroccan and Turkish children.

2. Significantly, the only monolingual Dutch child who is recorded produces one counterexample (oint of 5) with a definite direct object:

(i) en toen gingen ze een banaan kopen and then went they a banana buy-INF

[indigenous]

3. In monolingual child Dutch, the younger children may also combine an unaccusative verb such as weglopen 'walk-away' with gaan as a progressive auxiliary, as illustrated in (i) (Jordans 1990: 1433-34): (i) Jij gaat ook altijd weglope soms you go always walk-away-INF sometimes

'You are walking away'

4. Thanks to Louis Boumans for pointing this out to me.

\section{References}

Bennis, H. (to appear) 'Vl; de plaats van het werkwoord in multiculturele moppen'. In T. Meder, ed., Moppen vertellen in de multiculturele wijk Lombok.

Cornips, L. and W. Jongenburger. (1999) 'Het TCULT-project'. In E. Huls and B. Weltens, eds., Artikelen van de Derde Sociolinguitstische Conferentie. Eburon: Delft, 99-110.

Cornips, L. (to appear) 'Etnische variëteit van de Nederlandse kindertaal: aspectuele eigenschappen van gaan+infinitief.' Moppen vertellen in de multiculturele wijk Lombok

Holmes, J. (1997) 'Maori and Pakeha English: Some New Zealand social dialect data'. Language in Society $26: 1$.

De Hoop, H. (1992) Case configuration and Noun Phrase interpretation. PhD Dissertation, Groningen.

Jordens, P. (1990) 'The acquisition of verb placement in Dutch and English'. Linguistics 28, $1407-1448$.

Lalleman, J. (1986) Dutch language proficiency of Turkish children born in the Netherlands. Foris Publications: Dordrecht.

Müller, N., A. Hulk and C. Jakubowicz (1999) 'Object omissions in bilingual children: Evidence for crosslinguistic influence'. Proceedings of BUCLD 23, Vol. 2, 482-494.

Van Kampen, J. (1997) First steps in WH-movement. PhD Dissertation, Utrecht.

Zuckerman, S., R. Bastiaanse and R. van Zonneveld (1999) 'Verb movement in acquisition and aphasia: same problem different solutions. Evidence from Dutch'. Ms Graduate School for Behavorial and Cognitive Neurosciences and University of Groningen. 